\title{
Action Research with Technology Education Teachers: Experiences Gained during Learners Projects Supervision Process
}

\author{
Tomé Awshar, Mapotse \\ Department of Science and Technology Education \\ University of South Africa (UNISA), PO Box 392 Pretoria 0003 \\ mapotta@unisa.ac.za
}

\section{Doi:10.5901/mjss.2014.v5n2p507}

\section{Abstract}

This is an account of Action Research (AR) study, which was conducted in Limpopo Province of South Africa within Capricorn Region at Mankweng Circuit. Samples of five (5) secondary schools were used by engaging senior phase technology education (TE) teachers with cyclic and spiral intervention strategies of AR. This investigation intends to conscientise technology teachers with the important of emphasising technology process to their learners when they do their projects. To inculcate within teachers a culture of project process supervision, emancipation paradigm intervention was followed. These AR intervention strategies of observing, planning acting and reflecting with technology teachers yielded results that have emancipated the unqualified and under qualified technology teachers to take cognisance and diligently supervise each and every step of the technology process that their learners are passing through. The investigation incorporated structured interviews, logs of meetings, reflective questionnaires, non-participative observations and audio/visual capturing of lesson plans for data gathering. The study only reflects a week of engagement with TE teachers from the year long AR contact sessions. In every AR study data is harvested in any intervention with participants. The study reveals that the TE teachers were more interested with the end product of the process which is the project and less interested with the process of making the project. It is therefore recommended that technology teachers have a technology process monitoring tool which will guide them each and every step of the way to supervise their learners in project construction.

Keywords: Cyclic and Spiral Intervention Strategies; Technology Process; Learners Project/Products

\section{Introduction}

The world has changed more in the past two hundred years than it has throughout all previous history. The rate of change is continuing at an ever accelerating pace and is on an increasing magnitude, which is due to the advancement in both science and technology. Today, science and technology are moving ahead on a parallel path and each feeds the other and enables more advances as problems of our era are creatively solved (Toki Middle School, 2011). Technology or Design process is the backbone approach for teaching technology education whereas action research is process with emancipation intend to the participants. This paper is an account of the two processes combined within a study; those processes are action research process and technology process. Technology teachers need to expose their learners to all the steps of the technology process. The technology process has the following steps, Investigate, Design, Make, Evaluate and Communicate bearing an acronym IDMEC (DoE, 1996; 1997 DBE CAPS, 2011). Most technology teachers in the field are more interested in the technology products or projects developed by their learners rather than observing the technology process. This ignorance of succinctly checking and approving each and every technology/design process step of their learners undermine the aim of technology education.

Kufaine and Nyirenda (2013) recently emphasize that 'science and technology' as it is called in Malawi, is aiming at equipping the individual with knowledge, skills, values and attitudes that enables one to perform one's roles effectively in attempt to promote and sustain the socio economic development of a nation. Whereas (Nampota, Thompson and Wikeley, 2009) stressed that 'science and technology' is believed to be a catalyst for the development of both the individual and the nation. This technology subject is called in diverse names in different countries, for example in UK is termed 'Design and Technology', in USA is dubbed 'Technology Education', in Bangladesh is labelled 'Science and Technology' same as Malawi and in South Africa it is hailed as 'Technology Learning Area'. In this study I will use these technology education or technology concepts interchangeably. Many countries have made drastic changes in their existing school curriculum to create a space for TE in their curriculum (Mapotse, 2012). Teachers are still grappling with both the pedagogy and didactic of this fairly new technology subject (Pudi, 2007). 
In an article 'Community in, Commodity out', in the Guardian by Gaynor Aaltonen (in Wells, 2012) states that people are becoming far less interested in the product alone but they are far more interested in an all-embracing experience including the process as they interact with the product. Majority of teachers have a limited understanding of the technology process, because the in-service training that is being provided is more theoretical than hands-on (Nkosi, 2008). It is against this background that the study intends to share some light on an instrument developed to monitor the technology process during learners' technology product construction as a new contribution in the field of technology education teaching. This will be a proof that both the process and the product in technology education are inseparable. Even though technology education is a late comer in many school curricula both locally and globally, in this study, I sought to collaboratively engage senior phase technology teachers of selected schools in Limpopo Province of South Africa in Action Research for emancipation purposes of relating technology process well with technology products. This engagement exercise is prompted by National Ministry of Basic Education in South Africa under the 2014 Action Plan and Schooling 2025.

The National Department of Education (DoE) has unveiled the 2014 Action Plan and Schooling 2025 (The South African Schools Collection, 2012; Department of Basic Education, 2012). The plan outlines what the government will be doing to make Grade R to 12 schooling better. It is encouraging to note that the plan also explain how every one of the stakeholders in the schooling communities could contribute towards making the goals of the plan achievable. It is upon this background that in this article I intend sharing the negligence observed from technology teachers when undertaking to do technology projects, and to share my inputs as the stakeholder in the education ministry.

Quite number of scholars in the technology field has engaged in research targeting variety of aspects of technology education (TE). For instance Letsoalo (2007) undertook the study on 'The need for an instrument to monitor technology process during Technology projects'; Mapotse and Gumbo, (2011) shown their interest in 'A reconnaissance study into teaching of Technology in Limpopo Province schools; Pudi (2005) embarked on 'Educator roles for Technology Education teacher- educator'; Stevens (2006) invested time in unpacking 'Technology teacher education in South Africa'; Technomoodle (2010) took their readers through their research in 'The Design Process: Technology, Engineering, Design, and Virtual Learning Environment'; Tholo, Monobe and Lumadi (2011) studied 'What do boys and girls think about Technology?' whereas Williams and Gumbo, (2011) focus their study in 'New Zealand Technology pedagogical content knowledge'. The afore mentioned scholars belonging to both national and global villages have used some common instruments or similar approaches to gather their data and little has been done in using Action Research approach to emancipate technology teachers and conscientise them with learners supervision process of making the technology product. With this study I want to attempt to fill that gap by sharing experiences gained through project supervision. I will be sharing those technology teachers' experiences as a critical realist using emancipation paradigm and also underpinning this study through critical theory. If theory could be applied without any interrogation its influence on the study might not be noticed.

What is the teacher's worst enemy? Some would say lack of time. Others would say unsupportive leadership, or the dreaded government inspection. Rigid curriculum, lack of resources and bad student behaviour may also be high on the list for many educators. As for (Wheeler, 2012), the worst enemy is bad theory. Bad theory, when accepted without challenge, can lead to bad practice. It's insidious, because bad theory that is accepted as fact without a full understanding of its implications, results in bad teaching, and ultimately, learners will suffer. How I go about presenting this report is first to frame the study within the critical theoretical perspective and its application in the study. Second, I outline the research design and methods which is ensued by data analyses. I proceed by discussing the research findings and finally present both conclusions and recommendations developed from the findings.

\section{Theoretical Frameworks}

The study incorporated the approach taught by Stephen Kemmis and Robin McTaggart at Deakin University which stress the use of a defined cycle of research, and the use of participatory methods to produce 'emancipation'. They call their approach 'emancipatory action research', and draw on European sources, especially on the 'critical theory' of the Frankfurt school (Dick, 2010). The effort to conceptualize critical theory relied on the writings of Karl Marx (Tooley, 2000). Its basic purpose was emancipation and self-determination.

\subsection{Situating action research in an emancipatory paradigm}

Seeing that most of these technology teachers did not have prior training of technology during their tertiary training and 
are under qualified, it's imperative to engage in emancipatory paradigm with them. I will script out AR theory by following out the lead sentence from Creswell (1994).

\section{Textbox 2.1: Action Research Paradigm Script}

The paradigm I used was emancipatory paradigm for Action Research. It was developed by Paulo Freire,
and it was used to study methodology for intervention, development and change within communities and
groups. This paradigm indicate that it builds on the critical pedagogy put forward by Paulo Freire as a
response to the traditional formal models of education where the 'teacher' stands at the front and 'imparts'
information to the 'students' that are passive recipients (the paradigm challenges 'chalk-and-talk' as
technology is 'hands-on'). As applied to my study, this paradigm indicates that I would expect my
independent variables action research cycles ( $\rightarrow$ Planning $\rightarrow$ Action $\rightarrow$ Observation $\rightarrow$ Reflection $\rightarrow$ ) to
influence senior phase Technology Education teachers of Mankweng District in Limpopo Province to
supervise their learners' projects stage by stage.

The purpose of action research is to solve classroom problems through the application of scientific method. It is concern with a local problem and is conducted in a local setting. The primary goal of action research is the solution of a given problem not contribution to science. The value of action research is confined primarily to those conducting it (Gay, 1987). The purpose, concern, goal and value of action research were the order of every contact session with the participants throughout the AR cycles. I engaged the participants with participatory action research (PAR) activities in their technology education subject so that they will be confidence to engage their learners with a project and supervise the process of making that project.

\subsection{Framing the study within critical theoretical perspective}

I involved the co-researchers with critical theory (CT) so as to respond to the following research question: "What are the experiences gained by technology education teachers' during learners' projects construction supervision? The key challenges in underperforming schools are around textbooks, teacher development and time in schools (Fontannaz, 2012). This article share light around the middle raised challenge of technology teachers' development. In taking on this challenge, critical theory was sought as a guide to this action research study during the cycle process of decision making.Theory helped me in my thinking and making research decisions around the sense of teaching and learning technology. Theory is also an explanation that discusses how a phenomenon operates and why it operates as it does and it serves the purpose of making sense out of current knowledge by integrating and summarizing this knowledge, and thus it can be used to guide research by making predictions (Johnson and Christensen, 2004).

My choice of critical theory was motivated by my intent to emancipate the technology teachers in terms of overcoming the challenges that they faced in their supervision and evaluation of their learners' projects. By reflecting critically on their unfavourable status-quo of project assessment steps, technology teachers could be helped to think about how they could free themselves from such unfavourable conditions and take action about it - as a sign of emancipation. The kind of intervention in such involvement is to facilitative rather than instructive, so that those being helped can later be self-reliant and become independent to address their situation.

Hence, I assumed that engaging teachers in critical theory had the potential to improve their understanding about the knowledge and pedagogy of technology within their context. The next section discusses the research design and methods followed within this study.

\section{Research Design and Methods}

The collection of data is an important step in deciding what action needs to be taken. Multiple sources of data were used to better understand the scope of happenings in the technology classroom during project making. To address the research problem, an inquiry using a qualitative approach was undertaken to ascertain the opinions and experiences of technology teachers regarding the supervising of steps in constructing learners' project, with a view to further informing the project making agenda and technology process debates. This study was conducted with a small sample of five schools in Limpopo Province, with specific reference to learner projects supervision. 


\subsection{Outlining research design and methods incorporated}

With the guidance of the circuit manager, the five schools indicated in Table 3.1 (below) from Mankweng Circuit were chosen for their contextual location, convenience in conducting interviews and ease of convening a common venue for contact sessions of AR cycles and activities.

Table 3.1: Sample of selected schools and technology education teachers

\begin{tabular}{|l|c|c|c|c|c|c|c|}
\hline \multirow{2}{*}{$\begin{array}{c}\text { School } \\
\text { Name }\end{array}$} & Total & $\begin{array}{c}\text { Non-participative } \\
\text { Observations }\end{array}$ & $\begin{array}{c}\text { Structured } \\
\text { Interviews }\end{array}$ & $\begin{array}{c}\text { Logs of } \\
\text { Meetings }\end{array}$ & $\begin{array}{c}\text { Audio/Visual } \\
\text { recordings }\end{array}$ & $\begin{array}{c}\text { Reflective } \\
\text { Questionnaires }\end{array}$ & $\begin{array}{c}\text { School } \\
\text { Milieu }\end{array}$ \\
\cline { 2 - 8 } \\
\hline KMK Sec & 7 & 4 & 5 & 7 & None & 7 & Semi-Urban \\
\hline VMV Sec & 3 & 3 & 3 & 3 & 2 & 3 & Urban \\
\hline RMR Sec & 3 & 2 & 3 & 3 & None & 3 & Rural \\
\hline BMB Sec & 3 & 2 & 2 & 2 & 1 & 3 & Rural \\
\hline WHW Sec & 2 & 2 & 2 & 2 & 2 & 2 & Urban \\
\hline Total & 18 & 13 & 15 & 18 & 5 & 18 & \\
\hline
\end{tabular}

With pseudonyms assigned for the purposes of anonymity, schools were chosen within a radius of not more than 100 kilometres. The sampling varied in terms of their milieus, i.e., rural, urban and semi-urban, in order to gain biographical information on the need for intervention and degree of challenges they faced in supervising the learners projects. The number of TE teachers and their teaching varied, with some teaching only Grade 8, some only Grade 9. According to Tashakkori and Teddlie (2003), sampling involves selecting units of analysis (people, groups, artefacts, settings) in a manner that maximises the researcher's ability to answer the research question. In this study, I used cluster sampling among the cohort of teachers who were together in the General Education and Training band (Gay, 1987), namely senior phase technology teachers Members of the selected groups had homogeneous characteristics in that they all faced some challenges (Maree and Pietersen, 2010), in their teaching of technology. In cluster sampling the researcher identifies convenient naturally occurring groups units, such as neighbourhoods, schools, districts, or regions, from which a random selection is made (McMillan and Schumacher, 1989).

There are many vehicles for the collection of data but in this case I had to select those most appropriate for the issue being researched. Sources used during the main AR study were readily available and data collection was systematically organized and logically structured with the participants well in advance. I organized the data in a way that made it useful to identify trends and themes, collecting it from senior phase technology teachers of Mankweng Circuit through non-participant observations, audiovisual tapes of lesson presentations, interviews, field notes, logs of focus group meetings, and reflective questionnaires. The listed instruments are described briefly in the subsequent section.

\subsection{Synopsis description of action research instruments intergrated}

Obtrusive and unobtrusive varieties of research techniques used for project supervision purposes during AR study are briefly explained according to Kemmis and McTaggart (1988) and Wicks and Reason (2009). In explaining the instruments used in this study I would first introduce the instrument and then outline how I particularly employed it. The methods for collecting data are described as follows:

- Non-participative observation: A researcher sits at the back of the classroom but does not engage in the work of the group other than to record what is happening. In my case I sat at the front due to classroom learner congestion and used the observation grid within technology classes to record my observations. During the observation I jotted down some important moments and facts in conjunction with the grid, to be translated into field notes after the observation session.

- Use of video and audio records: A researcher uses a video camera and audio technology to record the actual events related to the research problem in the setting. Photographs make useful reference points for subsequent interviews and discussion of the data. I used both digital still cameras for photo-capturing and digital audiovisual for recording teachers' technology lesson presentations, as well as some of the meetings. This was carried out for later review and analysis.

- Interviews: These may be structured questions, as with the questionnaires, or unstructured, with the respondent given free rein to discuss ideas or opinions to prompt. It can be conducted face-to-face, via the 
internet or through telephone conversations. I engaged participants in face-to-face structured interviews between contact sessions, since I had worked out a series of questions to ask and to control the conversation as an interviewer.

- Questionnaires: These are self-report instruments, usually paper-based, completed by a respondent, with a series of questions either closed or open-ended. They constitute perhaps the most popular method of data collection in the social sciences and are essentially interviews by proxy; however a disadvantage may be low completion/return rates. In the case of this study I used reflective questionnaires at the end of each and every cycle for respondents to reflect on the session we had together. The advantage of this is that I had hundred percent return rates. This also helped me to plan the next session.

- Logs of focus group meetings/workshops/seminars: Cycle plans and activities thereof were jointly and fully discussed during meetings. During the contact sessions we ran several workshops around the theme or core content area of interest. On visiting participants at their own school I ran a seminar with them and their SMTs, and called them for member-checking on the last cycle of the study.

Corey (1953) wrote that the value of AR lies in the change that occurs in everyday practice rather than generalization to a broader audience. He saw the need for teachers and researchers to work together. However, in the mid-1950s, AR was attacked as unscientific, little more than common sense, and the work of amateurs (McFarland and Stansell, 1993). With AR now being considered more scientific, I will outline how I analysed the data from the above listed data gathering instruments in the section that ensue.

\section{Data Analysis}

Based on Table 3.1 data was collected using variety of instruments so as to supplement each other and validate the data. The investigation incorporated the following methods of data gathering non-participative observations, structured interviews, logs of meetings, audio/visual capturing of lesson plans and pictures, and reflective questionnaires. An observation grid was prepared in advance and analysis follows the pre-prepared topics from the grid. Thirteen (13) technology teachers were observed. Interviews to supplement what was observed were undertaken with fifteen (15) teachers from the five (5) schools. The interview analysis followed the topics on the pre-prepared interview schedule. Logs of meetings with all eighteen (18) participants was held with the intention of giving analysis feedback of both observation and interviews as well as engage in feed forward planning of lesson presentation recordings. A lesson plan evaluation instrument was design with the participants on previous cycles. It was during this meeting that analysis of teachers' presentation was shared with the teacher from all evaluators (peers and head of department). On the last day of the contact session we normally meet at a common place. On this last day of our contact session a reflective questionnaire (RQ) was given to all eighteen (18) participants to complete. I will collect all those questionnaires and analyse them as part of the feedback for the next contact session. The next contact session was structured with reference to the RQ feedback and teachers technology work schedule.

\section{Research Findings and Discussion}

The findings revealed that sample teachers' show an element of incapacity in terms of their knowledge and teaching of technology. In the areas of contextualising their teaching of technology teachers also need a special attention. In responding to the findings, the results prompt the development of the recommendations of a technology rubric to ensure that all the construction process steps are followed when constructing the technology product. This declaration is confirmed by Billy Cosby, (2009) who avers that, "If you want to know who really moulds our children's future, it's not the politicians, movie stars, or corporate leaders, but it's our teachers". The positive findings suggest that promotion of action research among senior phase technology teachers could lead to positive outcomes in teaching and learning of technology Siamese twins of technology education: technology process and technology product. Action research contributed to a more engaged, goal directed and reflective teaching with technology education teachers.

\subsection{Themes for fourth cycle project reflections}

During the contact session, participants were expected to reflect on their school experiences in engaging their learners with the chosen projects under the following sub-topics:

a) Core Knowledge: Processing. 
b) Circuit Theme: Containerisation.

- Challenges - time and materials.

- Success - workmanship:- skills learned presentation or communication, aesthetic and ergonomics.

- Gaps identified during the making of the project.

- Project roll-out by learners - duration, team work, capabilities, resources and assessment.

Each school had to share its experience openly with the team of researchers. I then requested the participants to file their reflection in their technology files. At the end of the third cycle I let the participants complete the interview questionnaire schedule, which, like in other cycles, I analysed. Analysis of participants' responses were discussed with and reported to them in the beginning of the fourth cycle.

\subsection{Vignette of both activities and findings from Cycle 4: At the contact session venue}

Core knowledge policy theme: Processing; Circuit theme: Containerization.

Topics and sub-topics for reflection:

\subsubsection{Challenges: time and materials}

Participants indicated that learners encountered an element of time constraint to an extent that the technology teachers ended up being a little bit pushy. The responses indicated challenges encountered: some learners did not submit their project on time; others' measurements were incorrect; learners were not active enough to design the dustbin; some learners used to leave their work at home; some were not participating. This did not come as a surprise because the teachers indicated that it was their first time that they experienced to engage their learners in project design and making. On the contrary, one teacher from one secondary school indicated:

"It is difficult for learners to collect materials and tools which are expensive like glue, measuring tapes and electrical equipment".

Concerning materials, things went on well as learners used readily available materials from their surroundings. However, some teachers encountered challenges:

"Material also contributed too much too time consuming. Some groups took much time to come up with materials as they reside about six to eleven kilometres far apart from each other".

\subsubsection{Success: workmanship,}

In many schools, learners' workmanship seems to be a very serious challenge to both teachers and learners, and in this case "learners did not trust each other especially when collecting materials. Some just relaxed". They "were arguing in doing the work. They were not working harmoniously with each other". Many of the teachers reported that their learners had not developed team spirit to achieve a specific goal. This had a direct bearing on the target date of submission.

\subsubsection{Gaps identified}

Participants argued that hand tools such as pliers needed to be purchased for future use. They also emphasized that consumable materials should always be available in order to speed up the learners' project turnaround time as it was felt that there was shortage of materials and lack of participation. These teachers' responses revealed that learners could not measure accurately and could not convert the units of measurements, e.g. centimetre to millimetre. One participant actually identified technology process as a matter of teacher unpreparedness and much attention was given to making of the product:

"Educators still need to be empowered more about the concepts, skills, technology steps and others".

\subsubsection{Project rollout by learners: Duration,}

The technology teachers gave the learners two weeks to design, complete and submit their projects. That was our 
agreement in the previous cycle. Nonetheless, learners' turnaround time differed from one school to another. At one school, one teacher responded, "my learners took a month and few days but only $70 \%$ of projects were submitted". Teachers responded further that majority of their learners showed commitment to their projects and were capable to deliver an envisaged project per grade. For this project in particular, resources were not an issue as learners' utilized recyclable material from their surroundings except those that reside in the school hostels.

Even though most of the learners projects where completed, I asked how they monitored the learners' progress when they work on their product, none of the educators come forth with any instruments to monitor the technology process. One teacher boosted about the learners' product by saying:-

"My learners are now lately good in making a project...just tell them what you want them to do, they will really impress you".

The educators noticed their weakness of not monitoring the technology process during technology product construction hence an instrument was recommended.

\subsection{AR Cycle 4: Feedback and reflections}

The following is a breakdown of the AR Cycle 4.

\subsubsection{Day 1}

RMR secondary school teachers brought along projects done by both Grade 8 and 9 learners for a show-off as agreed upon during the third cycle. This was for the first time teachers let their learners make Technology projects.

Teachers wrote down their reflections of the project process which covered the challenges encountered, gaps identified, and remedies. I handed out the weekly programme to those teachers present. I asked them about their Technology colleagues including those from other schools. They gave me different reasons why they could not come, like health related reasons. Copies of sections to be dealt with during the week were also given to teachers to prepare themselves. These were drafted based on their interview responses and work schedule.

\subsubsection{Day 2}

I travelled to other schools that were supposed to be part of the sessions in the Technology, who did not show up on Day 1. The early morning of Tuesday I just sent all the participants who were absent an SMS of concern to say that I had not seen them the previous day (Monday).

I then travelled to VMV secondary school. The MSTE HOD indicated that he had the exams so he could not attend the sessions. I then went to consult with Technology teachers through the HOD's permission. I was a bit shocked about their responses for not attending the sessions. Two teachers on contract from VMV School who were relieving those on maternity leave related their course of non-attendance as follows:

- "The HOD gave me another Technology project to do and I have to suspend the AR one".

- "Today is my last day at school as my contract ends today".

- "I was working on a contract and I am finishing on the end of June".

One of them promised to come on Wednesday.

\subsubsection{Day 3}

At WHW secondary school only three schools were represented save VMV for Day 3 sessions. A revision on graphics was made. An exercise on Electricity was given as a springboard to check the last session presentation. It was quite interesting since the answers were not the same. The debate continued until common consensus was reached guided by the responses given. Participants were asked to do some drawing activities at home and bring them on the following day - activities 7 and 9 from the manual provided.

\subsubsection{Day 4}


At least teachers' attendance was impressive except VMV secondary school. The session went on well, with graphics and introduction to mechanical systems and assessment discussed. The activities that were given to them pertaining to graphics were controlled. They were not done perfectly, accurately or competently. We were impressed by a lady teacher from RMR secondary school who had a perfect scale grid. She said that she was helped by a colleague who had a drawing background.

\subsubsection{Day 5}

Day 5 was the last day of Cycle 4 contact sessions. The participants had to structure the lesson presentation for the next cycle. The date, time and periods had to be coordinated from this session. The session started with all the participants from the three schools except VMV secondary school and other two schools joined us later. The session started with the unpacking of the Curriculum and Assessment Policy Statement (CAPS) documents. From the documents we learned that the LOs and Assessment Standards (ASs) are no more stated as they appeared in the Technology policy document.

Together we had to reflect on the session and plan for two weeks long Cycle 5 contact session. It was on this day that participants were jointly engaged in planning and reflecting on Cycle 4 together.

\section{Conclusions and Recommendations}

Hoban (2005) categorically stressed that, "teaching is more complex than it has ever been before. We need teachers, who are reflective, flexible, technology literate, knowledgeable, imaginative, resourceful, enthusiastic, team players and who are conscious of student differences and ways of learning". It can be possible to produce such a teacher only if Cohen \& Manion (1994) proposal can be considered as it emphasised that, "Action research is a small scale intervention in the functioning of a real world and a close examination of the effects of such intervention". With a sample of technology teachers, at selected schools of Limpopo Province, I will make some interventions and monitor their effect through AR cycles.

Research is an important way in which the field of technology education can become further established and teachers empowered. If we can agree that schools constitute the primary site of inquiry in technology education, then the ethos of classrooms and laboratories where the subject is taught must be a prime area of research need (Lewis, 1999). Seeing that schools can be used as a chief research base, the theories, methods and procedures chosen for the purpose of this study will be more applicable at schools around the Capricorn District

\section{References}

Cohen, L., Manion, L. \& Morrison, K. 2000. Research Methods in Education. London: Routledge Falmer.

Corey, S. M. 1953. Action Research to Improve School Practices. New York: Teachers College Press.

Cosby, B. 2012. About Technology Education. Online: 01/10/2013, Retrieved from: mhtml: file://B:ITE KITIAbout Technology Education.mht

Creswell, J.W.1994. Research Design. Qualitative and Quantitative Approaches. Thousand Oaks: Sage.

Department of Education.1996. Technology 2005: The HEDCOM Technology Education Project. Draft National Framework for Curriculum Development. Pretoria: Government Printers.

Department of Basic Education (DBE). 2010. Curriculum and Assessment Policy Statement (CAPS) Technology Grade 7 - 9 Final Draft [Online]. Accessed on: 15 November 2011. Available at: http://www.education.gov.za/CAPS.asp

Fontannas, S. (Ed). (2012). Education Handbook (3rd Annual). One Goal: Working together to achieve quality education. Stellenbosch: Argo.

Gay, L.R. (1987). Educational research: Competencies for analysis and application (3rd Ed.). Columbus: Merrill.

Department of Basic Education (DBE). 2011. Action Plan 2014: Towards the Realisation of schooling in 2025. Pretoria: Government Printers.

De Vos, A.S. (Ed), Strydom, H., Fouche, C.S. \& Delport, L.S.L. 2005. Research at Grass Roots (3rd Edition). Pretoria: Van Schaik.

Dick, B. 2010. Action Research Theses. Thesis resource paper. You want to do an action research thesis? Accessed on: 02 September 2010. Available at: http://www.scu.edu.au/schools/gcm /ar/art/athesis.html.

Johnson, B. \& Christensen, L. (2004). Educational research: Quantitative, qualitative and mixed approaches (2nd Ed.). Boston: Pearson. Kemmis, S., \& McTaggart, R. 1988. The Action Research Planner. Victoria - Australia: Deakin University Press.

Kufaine, N. \& Nyirenda, L. 2013. Science and Technology function literacy: case of Malawi. In Southern African Association for Research in Mathematics, Science and Technology Education (SAARMSTE). Proceeding of the 21st Annual meeting on "Making Mathematics, Science \& Technology Education - socially and culturally relevant in Africa". South Africa, University of Western Cape, Cape Province, $14-17$ January. 
Letsoalo, M. R. 2007. The need for an instrument to monitor technology process during Technology projects. Polokwane: University of Limpopo (BEd. Hon MST. Ed).

Mapotse, T.A. \& Gumbo, M.T. 2011. A reconnaissance study into teaching of Technology in Limpopo Province schools. Southern African Association for Research in Mathematics, Science and Technology Education (SAARMSTE). Proceedings of the

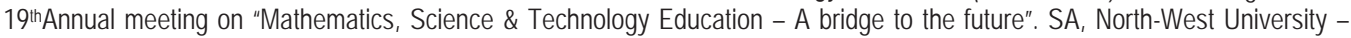
Making Campus, 18 - 21 January.

Mapotse, T.A. 2012. The teaching practice of senior phase Technology Education teachers in selected schools of Limpopo Province: an Action Research study. Pretoria: Unisa.

Maree, K (Ed). \& Pietersen, J. 2010. Sampling. In K. Maree (Ed.), First Steps in Research. Pretoria: Van Schaik.

McFarland, K. P. \& Stansell, J.C. 1993. Historical perspectives. In L. Patterson, C.M. Santa, C.G. Short, \& K. Smith (Eds.), Teachers are researchers: Reflection and action. Newark, DE: International Reading Association.

McMillan, J.H. \& Schumacher, S. (2nd Edition). 1989. Research in Education: A Conceptual Introduction. London: HarperCollins.

McNiff, J. \& Whitehead, J. 2009. Doing and writing action research. Los Angeles: Sage.

Mertens, D.M. 1998. Research Methods in Education and Psychology: Integrating Diversity with Quantitative and Qualitative Approaches. London: Sage.

Nampota, D. Thompson, J \& Wikeley, F 2009. The development of human capacity in Malawi: The role of 'science and technology'. International Review of Education: Vol. 55, pp 59 - 74

Nkosi, D.F. 2008. Technological process as a framework for the improvement of instruction of technology. MEd dissertation. Johannesburg: University of Johannesburg.

Potgieter, C. 2006. Linking the problem, the project and the design process. A retrospective view on introducing rural teacher to Technology Education. International Handbook of Technology Education: Reviewing the past twenty years. M. de Vries \& I. Mottier (Ed.). Rotterdam: Sense

Pudi, T.I. 2005. Educator roles for Technology Education teacher- educator. Africa Education Review, 34(1): 147-167.

Pudi, T.I (ed). 2007. Understanding Technology Education from a South African perspective, (pilot edition). Pretoria: Van Schaik.

Stevens, A. 2006. Technology teacher education in South Africa. International Handbook of Technology Education: Reviewing the past twenty years. M. de Vries \& I. Mottier (ed). Rotterdam: Sense.

Tashakkori, A. \& Teddlie, C. 2003. Handbook on mixed methods in the behavioural and social sciences. Thousand Oaks, CA: Sage.

Technomoodle. 2010. The Design Process: Technology, Engineering, Design, and Virtual Learning Environment. Online Classroom, retrieved on 30 May 2012 at http://www.technology education.org/Technomoodle/ thedesignprocess.html

Tholo, J.A.T., Monobe, R.J. \& Lumadi, M.W. 2011. What do boys and girls think about Technology? US-China Education Review, USA, 8(12), 2011.

Toki Middle School. 2011. About Technology Education. Online: 01/10/2013, Retrieved from: mhtml: file://B:ITE KITIAbout Technology Education.mht

Tooley, W. R. 2000. Political rationality \& government mechanisms: Maori education policy in the new millennium. MA in Education dissertation. Auckland: University of Auckland.

Wells, A. 2012. The importance of thinking for technological literacy: a phenomenological perspective. In an International Journal of Technology and Design Education.

Wheeler, S (Steve). (2012). Teacher's worst enemy. Accessed on 16/08/2013 from http://www.mustryharder.net/2012/08/teacher-worstenemy-link/

Whitehead, J. \& McNiff, J. 2006. Action Research Living Theory. London: SAGE.

Wicks, P.G. \& Reason, P. 2009. Initiating action research: Challenges and paradoxes of opening communicative space. SAGE (Online). Accessed on: 7 January 2010. Available at: http://arj.sagepub.com/cgi/content/abstract/7/3/243.

Williams, P.J. \& Gumbo, M.T. 2011. New Zealand Technology pedagogical content knowledge. In Pupils' Attitude Towards Technology (PATT) 25 and Centre for Research in Primary Technology (CRIPT) 8 on "Perspective on Learning in Design \& Technology Education". Goldsmiths, University of London, 29 June 2011 - 06 July 2011. 
E-ISSN 2039-2117

ISSN 2039-9340
Mediterranean Journal of Social Sciences MCSER Publishing, Rome-Italy
Vol 5 No 2 January 2014 